\title{
Radon and thoron anomalies along Mat fault in Mizoram, India
}

\author{
Hari Prasad Jaishi ${ }^{1}$, Sanjay Singh ${ }^{1}$, Raghavendra Prasad Tiwari ${ }^{2}$ \\ and Ramesh Chandra Tiwari ${ }^{1, *}$ \\ ${ }^{1}$ Department of Physics, Mizoram University, Aizawl 796 004, India. \\ ${ }^{2}$ Department of Geology, Mizoram University, Aizawl 796 004, India. \\ ${ }^{*}$ Corresponding author.e-mail: ramesh_mzu@rediffmail.com
}

In this study, radon and thoron concentrations in soil gas has been monitored using LR-115(II) solid state nuclear track detectors since 15th July 2011 to February 2012. The study was carried out along Mat fault in Serchip district, Mizoram, India at two different sites - Mat Bridge $\left(23^{\circ} 18^{\prime} \mathrm{N}, 92^{\circ} 48^{\prime} \mathrm{E}\right)$ and Tuichang $\left(23^{\circ} 13^{\prime} \mathrm{N}, 92^{\circ} 56^{\prime} \mathrm{E}\right)$. The results obtained have been correlated to the seismic events that occurred within $800 \mathrm{~km}$ from the measuring sites over the mentioned period of time. Anomalous behaviour in radon concentrations have been observed prior to some earthquakes. Interestingly, some thoron anomalies were also recorded.

\section{Introduction}

Earthquake has become a major topic which draws the attention of many researchers as it is one of the most devastating natural calamities and till today there is no established technique evolved which can predict earthquakes exactly. However, variations in some of the gases like $\mathrm{CO}_{2}, \mathrm{He}, \mathrm{H}_{2}, \mathrm{Rn}$, $\mathrm{CH}_{4}$ and $\mathrm{N}_{2}$ and highly volatile metals such as $\mathrm{Hg}$, Sb and As could be possibly used to predict earthquakes as they release out from the activefault region (Vaupotic et al. 2010). Of all these, variations of radon concentration along the active fault region is the most widely used as a possible precursor to earthquakes (Sac et al. 2011).

The history of the relationship between radon concentration and earthquake dates back to the year 1966. It was observed that there was an increase in radon concentration in the Russian wells before the Tashkent earthquake of 1966. Later in the year 1974, Birchfard and Libby installed the first site to measure radon concentrations in the soil. After that, it was well known that the radon concentrations in the soil and underground water could be used as a possible precursor to earthquakes (Vaupotic et al. 2010). Studies relating to the variation of radon concentration (underground and well water) and its correlation to seismic events have been studied in different parts of the globe (King et al. 1981; O'Neil and King 1981; Shapiro et al. 1981; King 1986; Sano et al. 1986; Sugisaka and Sugiura 1986; Igarashi and Wakita 1990; Honkura and Isikara 1991; Monnin and Seidel 1991; Wakita 1996; Zmazek et al. 2002, 2003; Walia et al. 2005; Kuo et al. 2006; Ghosh et al. 2009; Vaupotic et al. 2010). As far as known to the authors, the studies on radon and thoron anomalies as a precursor to earthquakes had not been done in the northeastern region in general and Mizoram, in particular. However, some authors (Dwivedi et al. 1995; Srivastava et al. 1996) recorded radon data in dwellings. Ghosh et al. $(2009,2011)$ have done the soil radon study and its correlation to seismic events at Darjeeling and Jalpaijuri respectively in the state

Keywords. Radon; thoron; LR-115(II) detectors; correlation; seismic events. 

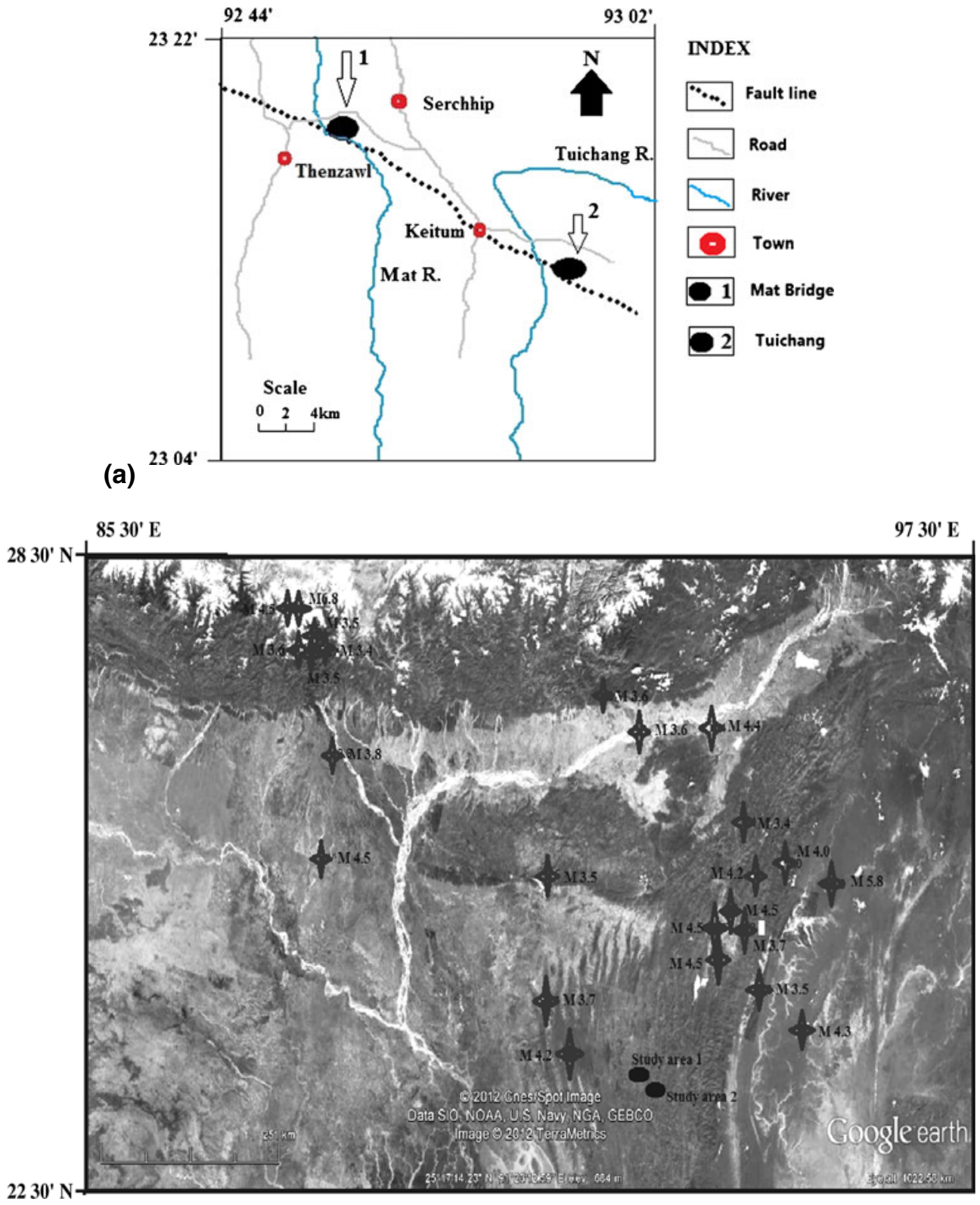

(b)

Figure 1. (a) Location map of the study area and (b) spatial distribution of earthquakes around the study area.

of West Bengal which is the nearest possible sites of measurements from our measuring sites.

Mat fault is the most prominent fault in Mizoram state. It obliquely cuts across the general north-south trend of the Indo-Burmese arc. It trends NW-SE and is traceable across entire Mizoram on the satellite as well as on the geological maps. Mat River crosses the Mat fault and follows it for considerable distance. Most pronounced part of this fault is in Serchhip district along SerchhipThenzawl road (Malsawma et al. 2010). Figure 1 shows the geological settlement of the study area. Hence, this part has been selected for monitoring of radon and thoron anomaly and their possible correlation with the occurrence of earthquakes. This study aims to correlate radon and thoron anomalies to seismic events.

\section{Materials and methods}

Radon and thoron measurements in the soil were carried out using LR-115 Type II films, manufactured by M/S Kodak Pathe, France at two different sites Mat Bridge and Tuichang separated by a distance of $35 \mathrm{~km}$ approximately. The cellulose nitrate films were cut into a size of $3 \mathrm{~cm} \times 3 \mathrm{~cm}$ 


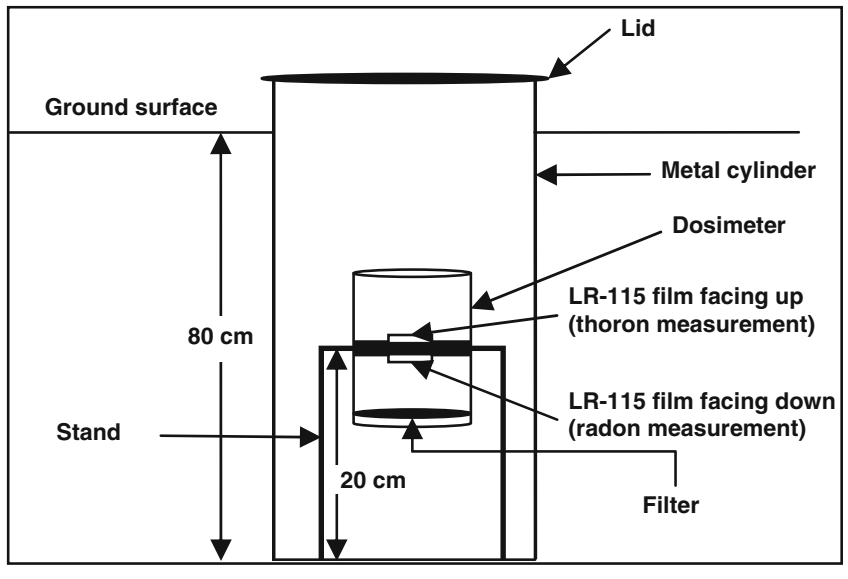

Figure 2. Radon and thoron measurements in soil.

and loaded in the dosimeters which provide three modes of exposures (two bare modes and one filter mode) to determine radon and thoron along with their progeny simultaneously. In our case we use only two modes - bare mode to detect thoron and its progeny and filter mode to detect radon. Holes were dug $80 \mathrm{~cm}$ below the surface and $30 \mathrm{~cm}$ in diameter, total of five holes on each site $2 \mathrm{~m}$ apart from each other. Figure 2 shows the method of measuring radon and thoron in the soil. Metal cylinders with the bottom open and top with a lid were inserted on these holes. The dosimeters containing the films were then placed inside the cylinders. Each dosimeter contains two films. The films were exposed for a period of 15 days after which they were removed and replaced by new films. The recovered films from the soils were then chemically etched in $2.5 \mathrm{~N} \mathrm{NaOH}$ solutions for $1 \mathrm{~h}$ in a constant temperature bath. The purpose of the etching process is to enlarge the alpha track registered from radon gas in the soil. The temperature of the etching bath during this process was kept stable at $60{ }^{\circ} \mathrm{C}$. After etching, the films were washed in running water and then kept in the distilled water for $2 \mathrm{~h}$. Immediately after the completion of this process the sensitive layer of the films were stripped. The stripped LR-115 films are then dried and used for track counting using a spark counter.

\section{Results and discussion}

Radon and thoron concentrations in soil have been measured after every 15 days using a SSNTD, LR115(II) films at two different measuring sites, Mat Bridge and Tuichang in Serchhip district, Mizoram (India). Apart from the seismic events, the meteorological parameters, viz., rainfall, temperature, humidity, pressure and wind velocity also influence radon exhalation (Kraner et al. 1964; Pearson
1967; Gabelman 1972; Steele 1981; Singh et al. 1988; King and Minissale 1994; Singh and Virk 1994; Sharma et al. 2000; Virk et al. 2000; Mukherji et al. 2001; Zmazek et al. 2003; Walia et al. 2005; Ghosh et al. 2011). In a study in NW Himalaya, a group of authors (Virk and Singh 1992; Sharma et al. 2000; Walia et al. 2005) reported that the radon concentration is maximum in the summer rainy season (July-September) and minimum during the winter season (November-February). This may be due to the capping effect of the wet soil layers at the surface which prevents radon from escaping into the atmosphere (Kraner et al. 1964; Jaacks 1984; Hesselbom 1985; Singh et al. 1988; Virk et al. 2000). Due to nonavailability of meteorological data near the selected sites as of now, we are unable to carry out such analysis at present. The radon concentrations have been recorded from 15 July 2011-February 2012 and thoron concentrations from October 2011-February 2012. Figure 3 represents the radon concentrations at Mat Bridge and Tuichang over the said period of time and figure 4 represents the thoron concentrations for the same sites. Dobrovolsky et al. (1979) and Fleischer (1981) proposed the relationship between the magnitude (M) of the earthquake and the epicentre distance (D) within which the earthquake prediction zone can be manifested.

$$
\begin{gathered}
\mathrm{D}=10 \exp 0.43 \mathrm{M} \mathrm{km}, \\
\quad(\text { Dobrovolsky et al. } 1979) \\
\mathrm{D}=(10 \exp 0.48 \mathrm{M}) / 1.66 \mathrm{~km} \text { for } \mathrm{M}>3 \\
(\text { Fleischer 1981). }
\end{gathered}
$$

In the present investigation, attempts have been made to understand the relationship between radon anomaly and the epicentre distance of an earthquake. The concentrations have been calculated in terms of $\mathrm{Bq} / \mathrm{m}^{3}$. Even though the pits are separated $2 \mathrm{~m}$ apart, large variation in radon concentration were observed between the two pits. The maximum variation in radon concentration was recorded during the month of August at both the sites. At Mat Bridge, the maximum variation was recorded to be $6212 \mathrm{~Bq} / \mathrm{m}^{3}$ and at Tuichang $1946 \mathrm{~Bq} / \mathrm{m}^{3}$. This variation may or may not be due to the capping effect. However, the authors are unable to explain clearly the reason at this juncture. The plotted value of radon concentration is the average of all five pits measurements. The locations of earthquakes over the mentioned period of time and its epicentre distances from the measuring sites have been highlighted in table 1 . Radon concentration at both the sites tends to show similar characteristics except that an increase in radon concentration was observed at Mat Bridge (which occurred on 45th day of the observation 


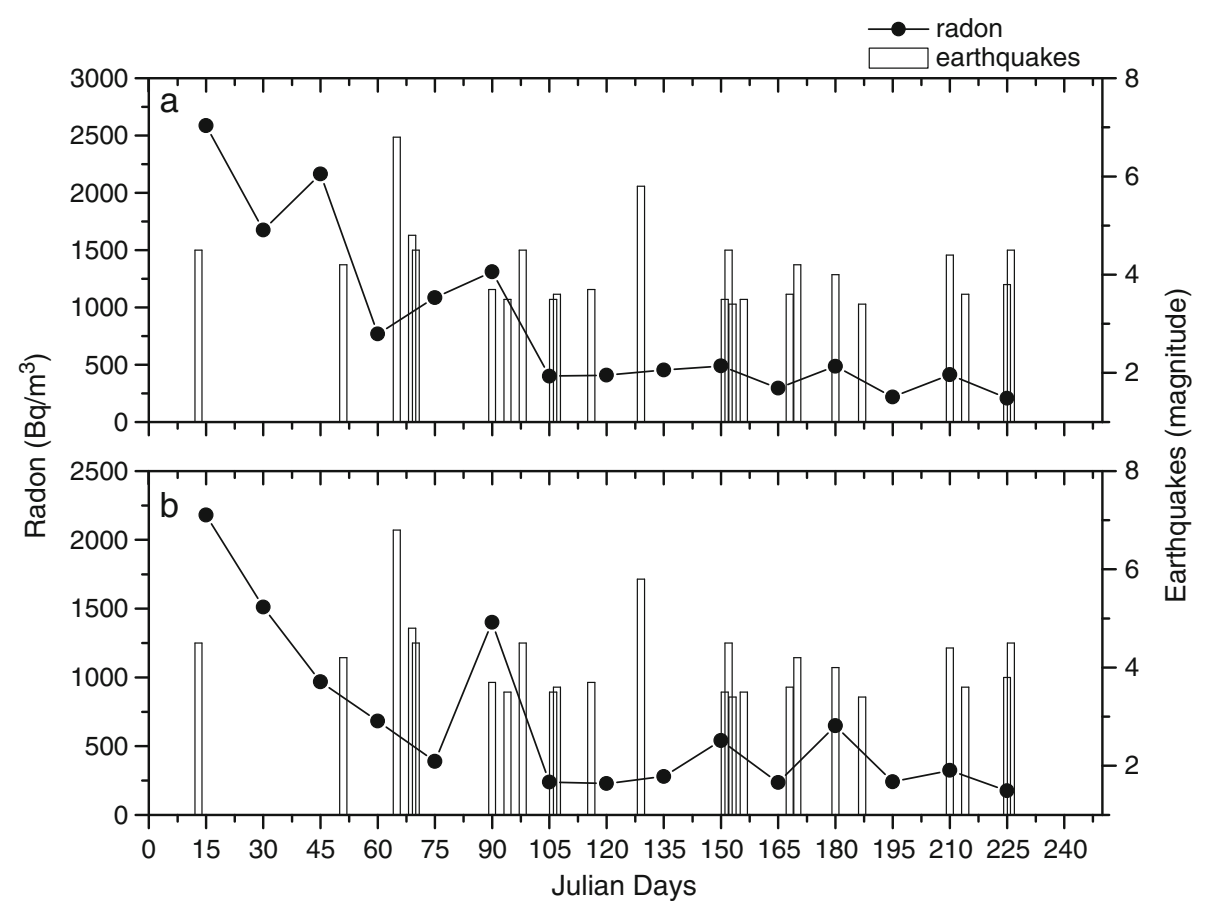

Figure 3. Radon concentration and the corresponding earthquakes. (a) Mat Bridge and (b) Tuichang.

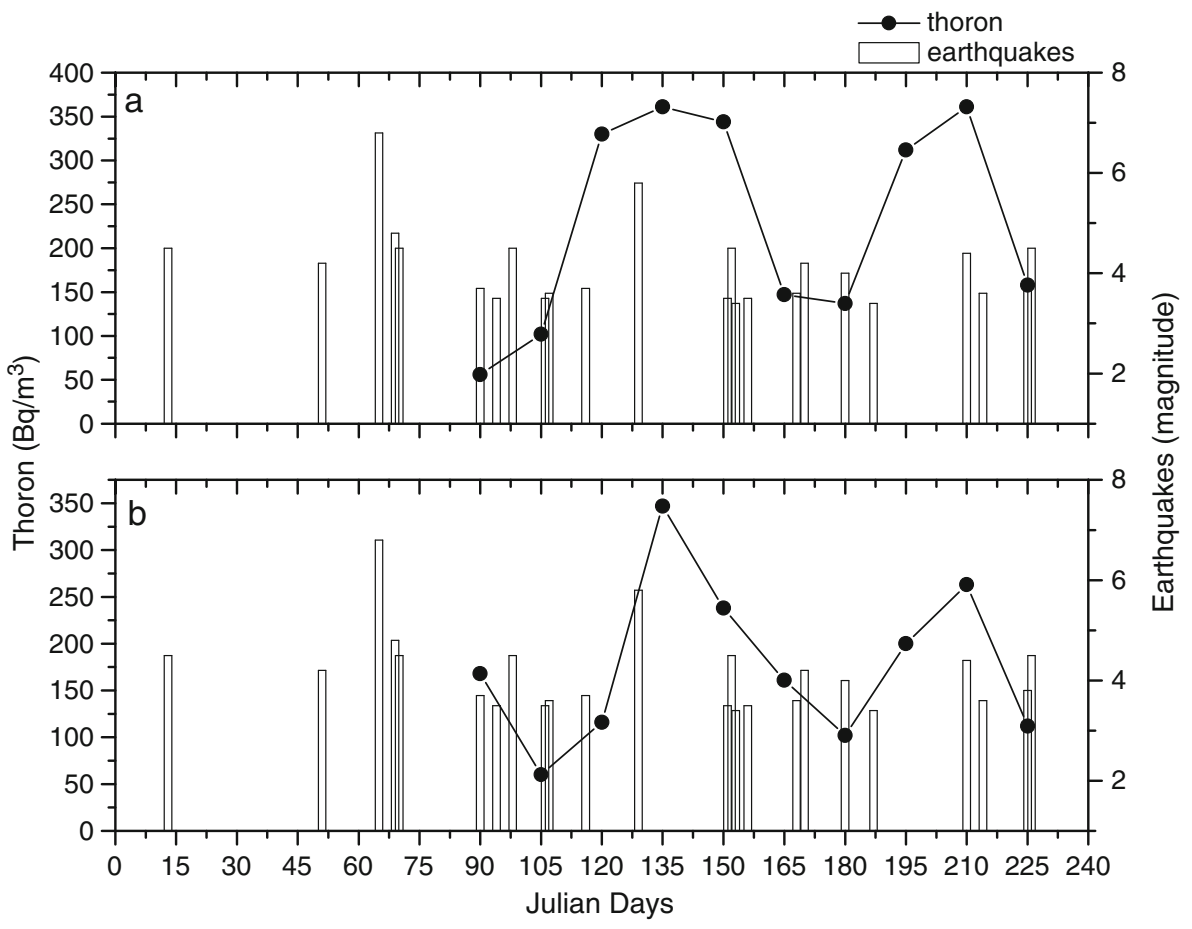

Figure 4. Thoron concentration and the corresponding earthquakes. (a) Mat Bridge and (b) Tuichang.

period, figure 3a) whereas no such observation was recorded at Tuichang (figure 3b). This increase in radon concentration may be treated as an anomaly before the signal earthquake of M6.8 (which occurred on 65th day of the observation period at a distance of $674 \mathrm{~km}$ from the measuring site; 20 days after the anomaly was observed).
However, an earthquake of M4.2 (which occurred on 51st day of the observation period at a distance of $260 \mathrm{~km}$ ) was also recorded just 6 days after the anomaly was observed, but this may not be considered as a signal earthquake because the epicentral distance does not fall in the earthquake preparation zone as per equation (2). Our results 
Table 1. Details of locations of earthquakes observed from the measuring sites. (source: usgs/imd)

\begin{tabular}{|c|c|c|c|c|c|c|}
\hline \multirow[b]{2}{*}{ Date } & \multirow{2}{*}{$\begin{array}{l}\text { Days (Julian) } \\
\text { of occurrence } \\
\text { of earthquake }\end{array}$} & \multirow{2}{*}{$\begin{array}{l}\text { Latitude and } \\
\text { Longitude }\end{array}$} & \multicolumn{2}{|c|}{ Distance of epicentre $(\mathrm{km})$} & \multirow[b]{2}{*}{ Magnitude } & \multirow[b]{2}{*}{ Region } \\
\hline & & & Mat Bridge & Tuichang & & \\
\hline 28.07 .2011 & 13th day & $25.3^{\circ} \mathrm{N}, 88.6^{\circ} \mathrm{E}$ & 481 & 497 & 4.5 & $\begin{array}{l}\text { India (W. Dinajpur)- } \\
\text { Bangladesh Border region }\end{array}$ \\
\hline 04.09 .2011 & 51st day & $25.2^{\circ} \mathrm{N}, 94.3^{\circ} \mathrm{E}$ & 260 & 261 & 4.2 & Ukhrul, Manipur \\
\hline 18.09.2011 & 65 th day & $27.7^{\circ} \mathrm{N}, 88.2^{\circ} \mathrm{E}$ & 674 & 689 & 6.8 & Sikkim-Nepal Border region \\
\hline 22.09 .2011 & 69th day & $23.7^{\circ} \mathrm{N}, 94.9^{\circ} \mathrm{E}$ & 218 & 208 & 4.8 & Myanmar \\
\hline 23.09.2011 & 70th day & $24.4^{\circ} \mathrm{N}, 93.8^{\circ} \mathrm{E}$ & 159 & 158 & 4.5 & Imphal \\
\hline 13.10 .2011 & 90th day & $24.0^{\circ} \mathrm{N}, 91.5^{\circ} \mathrm{E}$ & 158 & 175 & 3.7 & $\begin{array}{l}\text { India (Tripura)-Bangladesh } \\
\text { Border region }\end{array}$ \\
\hline 17.10 .2011 & 94th day & $27.3^{\circ} \mathrm{N}, 88.4^{\circ} \mathrm{E}$ & 628 & 644 & 3.5 & Sikkim \\
\hline 21.10 .2011 & 98th day & $24.8^{\circ} \mathrm{N}, 94.0^{\circ} \mathrm{E}$ & 206 & 207 & 4.5 & Imphal \\
\hline 29.10 .2011 & 106th day & $27.4^{\circ} \mathrm{N}, 88.4^{\circ} \mathrm{E}$ & 636 & 652 & 3.5 & Sikkim \\
\hline 30.10 .2011 & 107th day & $26.9^{\circ} \mathrm{N}, 92.3^{\circ} \mathrm{E}$ & 403 & 414 & 3.6 & $\begin{array}{l}\text { Assam-Arunachal Pradesh } \\
\text { Border region }\end{array}$ \\
\hline 08.11 .2011 & 116th day & $24.7^{\circ} \mathrm{N}, 94.2^{\circ} \mathrm{E}$ & 211 & 209 & 3.7 & Ukhrul, Manipur \\
\hline 21.11 .2011 & 129th day & $25.1^{\circ} \mathrm{N}, 95.3^{\circ} \mathrm{E}$ & 324 & 320 & 5.8 & Myanmar-India Border region \\
\hline 13.12.2011 & 151st day & $25.2^{\circ} \mathrm{N}, 91.5^{\circ} \mathrm{E}$ & 250 & 264 & 3.5 & $\begin{array}{l}\text { India(Meghalaya)-Bangladesh } \\
\text { Border region }\end{array}$ \\
\hline 14.12 .2011 & 152nd day & $27.7^{\circ} \mathrm{N}, 88.0^{\circ} \mathrm{E}$ & 687 & 703 & 4.5 & $\begin{array}{l}\text { India(Sikkim)-Nepal Border } \\
\text { region }\end{array}$ \\
\hline 15.12.2011 & 153rd day & $25.7^{\circ} \mathrm{N}, 94.1^{\circ} \mathrm{E}$ & 298 & 300 & 3.4 & $\begin{array}{l}\text { Assam-Nagaland Border } \\
\text { region }\end{array}$ \\
\hline 18.12 .2011 & 156th day & $24.1^{\circ} \mathrm{N}, 94.3^{\circ} \mathrm{E}$ & 177 & 171 & 3.5 & India-Myanmar Border region \\
\hline 30.12 .2011 & 168th day & $26.5^{\circ} \mathrm{N}, 92.8^{\circ} \mathrm{E}$ & 356 & 365 & 3.6 & Assam \\
\hline 01.01.2012 & 170th day & $23.5^{\circ} \mathrm{N}, 91.8^{\circ} \mathrm{E}$ & 105 & 120 & 4.2 & Southern Tripura \\
\hline 11.01.2012 & 180th day & $25.3^{\circ} \mathrm{N}, 94.7^{\circ} \mathrm{E}$ & 294 & 293 & 4.0 & $\begin{array}{l}\text { India (Manipur)-Myanmar } \\
\text { Border region }\end{array}$ \\
\hline 18.01.2012 & 187th day & $27.3^{\circ} \mathrm{N}, 88.5^{\circ} \mathrm{E}$ & 621 & 636 & 3.4 & Sikkim \\
\hline 10.02 .2012 & 210 th day & $26.6^{\circ} \mathrm{N}, 93.7^{\circ} \mathrm{E}$ & 380 & 386 & 4.4 & $\begin{array}{l}\text { Assam-Nagaland Border } \\
\text { region }\end{array}$ \\
\hline 14.02.2012 & 214 th day & $27.3^{\circ} \mathrm{N}, 88.2^{\circ} \mathrm{E}$ & 642 & 658 & 3.6 & $\begin{array}{l}\text { India (Sikkim)-Nepal Border } \\
\text { region }\end{array}$ \\
\hline 25.02 .2011 & 225 th day & $26.3^{\circ} \mathrm{N}, 88.7^{\circ} \mathrm{E}$ & 533 & 549 & 3.8 & $\begin{array}{l}\text { Bangladesh-India (WB) } \\
\text { Border region }\end{array}$ \\
\hline 26.02 .2012 & 226 th day & $24.7^{\circ} \mathrm{N}, 93.7^{\circ} \mathrm{E}$ & 181 & 188 & 4.5 & Manipur \\
\hline
\end{tabular}

show that at Tuichang (figure $3 \mathrm{~b}$ ), no increase in radon concentration was observed (as in case of Mat Bridge, figure 3a) before the strong earthquake of M6.8 from the starting day of measurement. In fact the radon concentration tends to decrease. This abrupt decrease may be either due to additional compression closing cracks and pores (Singh et al. 1991; Ramola et al. 2008) or from expansion causing temporary undersaturation of the pore volume (Whitcomb 1983). An anomalous increase in radon concentration which results due to crustal deformation in the region (Walia et al. 2009) was observed at both the sites which occurred on 90th day of the observation period (figure 3 ). This can be treated as an anomaly before the earthquake of M5.8 (129th day of the observation period; 39 days after the anomaly was observed) which occurred at a distance of $324 \mathrm{~km}$ from Mat Bridge and $320 \mathrm{~km}$ from Tuichang. Some series of earthquakes; M3.7 (occurred on 90th day, $158 \mathrm{~km}$ from Mat Bridge and $175 \mathrm{~km}$ from Tuichang), M3.5 (occurred on 94th day, $628 \mathrm{~km}$ from Mat Bridge and $644 \mathrm{~km}$ from Tuichang) and M4.5 (occurred on 98th day, $206 \mathrm{~km}$ from Mat Bridge and $207 \mathrm{~km}$ from Tuichang) happen close to each other but these events cannot be correlated to the anomaly observed as the epicentral distances do not fall in the earthquake preparation zone in accordance with equation (2). Interestingly some thoron anomalies were also recorded in both the sites. There was a sudden increase in thoron concentration approximately 1 week before the earthquake of M5.8 which occurred on 129th 
day of the observation period (figure 4) at a distance of $324 \mathrm{~km}$ from Mat Bridge and $320 \mathrm{~km}$ from Tuichang. The thoron concentration reaches a maximum value 7 days after the earthquake. Other interesting observation is that abrupt increase in thoron concentrations have been observed just prior to the M4.4 earthquake which occurred on 210 th day of the observation period $(380 \mathrm{~km}$ from Mat Bridge, $386 \mathrm{~km}$ from Tuichang). However, no significant changes in radon concentration were observed during the same period. The reason may be due to the carrier gases which play a dominant role in controlling the transport of radon gas towards the earth surface fault zone (Etiope and Martinelli 2002). This can also be understood on the basis of closer and shallower gas source which provide small amount of radon/thoron gas to the surface due to micro factures before moderate earthquake. Such small amount of gas may not increase radon concentration due to its original relatively high background level rather increases thoron concentrations (Yang et al. 2005).

\section{Conclusion}

In our study, some rise and fall in radon concentration have been recorded prior to the earthquakes of M6.8 and M5.8. We observed unusual behaviour in radon concentrations. Sharp fall in radon concentration were recorded just before the large earthquake of M6.8 at Tuichang. On the other hand, out of all the thoron anomalies recorded it was found that an increase in thoron concentrations was associated with the earthquakes. The M6.8 earthquake was the largest that occurred in the region over the mentioned period of time. Due to topographic difficulties LR-115 films are replaced at 15 days interval do not appear to be sufficient enough to pinpoint or correlate with seismic activity. However, the recorded data shows certain positive radon and thoron anomalies which preceded the earthquakes. The present study shows the usefulness of such data in further studies. In future, authors will try to carry out daily recording of data. The unusual anomalies observed in the present investigation may provide soil radon/thoron database and preliminary trends of their response to seismic activity in the selected fault region; the most prominent fault in Mizoram, but does not provide sufficient evidence for correlation or predicting earthquakes. Therefore the present work needs further investigation. Long term and continuous observation is necessary to confirm a relation between the seismic events and radon concentration.

\section{Acknowledgements}

Authors are grateful to the Ministry of Earth Sciences, Govt. of India, New Delhi for their financial support in the form of Major project vide Sanction Order No. MoES/ P.O.(Seismo) /1(67)/2009, dated 16-06-2010.

\section{References}

Dobrovolsky I P, Zubkov S I and Miachkin V I 1979 Estimation of the size of earthquake preparation zones; Pure Appl. Geophys. 117 1025-1044.

Dwivedi K K, Srivastava A, Ghosh S, Sinha D, Laldawngliana C, Lalramengzami R and Saxena A 1995 Measurements of indoor radon in some dwellings in Aizawl (India); Indoor Environ. 4 362-364.

Etiope G and Martinelli G 2002 Migration of carrier and trace gases in the geosphere: An overview; Phys. Earth Planet. Int. 129 185-204.

Fleischer R L 1981 Dislocation model for radon response to distant earthquakes; Geophys. Res. Lett. 8 477-480.

Gabelman J W 1972 Radon emanometry of Straks Salt Dome Calcasiea Parish, Louisiana; U.S. Energy Commission Rep. RME-414, 75p.

Ghosh D, Deb A, Haldar S, Sahoo S R and Sengupta R 2009 Radon time series and earthquake signals - a study by SSNTD at Matigara (Darjeeling), India; e-J. Earth Sci. India 2(2) 76-82.

Ghosh D, Deb A, Sahoo S R, Haldar S and Sengupta R 2011 Radon as seismic precursor: New data with well water of Jalpaiguri, India; Natural Hazards 58(3) 877-889.

Hesselbom A 1985 Radon in soil gas: A study of methods and instruments for determiningradon concentrations in the ground, Uppsala, Sweden; Sveriges Geologiska Undersokning, Ser. C. 803 1-58.

Honkura Y and Isikara A M 1991 Multidisciplinary research on fault activity in the western part of the North Anatolian Fault Zone; Tectonophys. 193(4) 347-357.

Igarashi G and Wakita H 1990 Groundwater radon anomalies associated with earthquakes; Tectonophys. $1802-4$.

Jaacks J A 1984 Meteorological influence upon mercury, radon and helium soil gas emissions; Ph.D. Thesis, Colorado School of Mines.

King C Y 1986 Gas geochemistry applied to earthquake prediction: An overview; J. Geophys. Res. 91(B12) 12,269.

King C Y, Evans W C, Presser T and Husk R H 1981 Anomalous chemical changes in well waters and possible relation to earthquakes; Geophys. Res. Lett. 8 425-428.

King C Y and Minissale A 1994 Seasonal variability of soil-gas radon concentration in central California; Radiat. Meas. 23 683-692.

Kraner H W, Schroeder G L and Evans R D 1964 Measurements of the effects of atmospheric variables on radon-222 flux and soil gas concentration; In: The Natural Radiation and Environment (eds) Adams J A S and Lower W M, Univ. Chicago Press, Chicago, pp. 191-215.

Kuo T, Fan K, Kuochen H, Han Y, Chu H and Lee Y 2006 Anomalous decrease in groundwater radon before the Taiwan M6.8 Chengkung earthquake; J. Environ. Radioac. 88 101-106.

Malsawma J, Lalnuntluanga P, Wadekar A, Sangode S J and Tiwari R P 2010 Magnetic polarity stratigraphy of the Bhuban succession, Surma Group, Tripura-Mizoram Accretionary Belt, India; J. Geol. Soc. of India 76(1) 119-133. 
Monnin M M and Seidel J L 1991 Radon and geophysics: Recent advances; Int. J. Radiation Application and Instrumentation. Part D. Nuclear Tracks and Radiation Measurement 19(1-4) 375-382.

Mukherji P, Chatterjee M and Sen K G 2001 Mathematical modelling of radon emanation for earthquake prediction; In: Proc. 5th Int. Conf. Rare Gas Geochemistry (eds) Hunyadi I, Csige I and Hakl J, Ep Systema, Debrecen, Hungary, pp. 27-35.

O'Neil J R and King C Y 1981 Variations in stable isotope ratios of groundwaters in seismically active regions of California; Geophys. Res. Lett. 8 429-432.

Pearson J E 1967 Natural Environmental Radioactivity from Radon-222; Public Health Serv. Publ. 999-RH-26. U.S. Dept. of Health, Education and Welfare, Washinton D.C., $31 \mathrm{p}$.

Ramola R C, Prasad Y, Prasad G, Kumar S and Choubey V M 2008 Soil-gas radon as seismotectonic indicator in Garhwal Himalaya; J. Appl. Radiat. Isot. 66 1523-1530.

Sac M M, Harmansah C, Camgoz B and Sozbilir H 2011 Radon monitoring as the earthquake precursor in fault line in Western Turkey; Ekoloji. 20(79) 93-98.

Sano Y, Nakamura Y, Wakita H, Notsu K and Kobayashi $\mathrm{Y} 1986{ }^{3} \mathrm{He} /{ }^{4} \mathrm{He}$ ratio anomalies associated with the 1984 western Nagano earthquake: Possibly induced by a diapiric magma; J. Geophys. Res. 91 12,291-12,295.

Shapiro H H, Melvin J D, Tombrello T A, Mendenhall H H, Larson P B and Whitcomb J H 1981 Relationship of the 1979 Southern California radon anomaly to a possible regional strain event; J. Geophys. Res. 86 17251730 .

Sharma A K, Walia V and Virk H S 2000 Effect of meteorological parameters on radon emanation; J. Geophys. 21 47-50.

Singh B and Virk H S 1994 Investigation of radon-222 in soil-gas as an earthquake precursor; Nucl. Geophys. 8 185-193.

Singh M, Ramola R C, Singh B, Singh S and Virk H S 1991 Subsurface soil gas radon changes associated with earthquakes; Int. J. Radiat. Appl. Instrum., Part D. 19(1-4) 417-420.

Singh M, Ramola R C, Singh N P, Singh S and Virk H S 1988 Influence of meterological parameters on soil gas radon; J. Assoc. Explor. Geophys. 9 85-90.

Srivastava A, Lalramengzami R, Laldawngliana C, Sinha D, Ghosh S, Dwivedi K K, Saxena A and Ramachandran T V 1996 Measurement of Potential Alpha Energy Exposure (PAEE) of radon and its progenies in dwellings in the north-eastern region of India; Radiat. Meas. 26(2) 291-295.

Steele S R 1981 Radon and hydrologic anomalies on the rough creek fault: Possible precursor to the M5.1 eastern Kentucky earthquake, 1980; Geophys. Res. Lett. 8 441-444.

Sugisaki R and Sugiura T 1986 Gas anomalies at three mineral springs and a fumarole before an inland earthquake, central Japan; J. Geophys. Res. 91 12,296-12,304.

Vaupotic J, Riggio A, Santulin M, Zmazek B and Kobal I 2010 A radon anomaly in soil gas at Cazzaso, NE Italy, as a precursor of an $M_{\mathrm{L}}=5.1$ earthquake; Nukleonika. 10 895-899.

Virk H S and Singh B 1992 Correlation of radon anomalies with earthquake in Kangra Valley; Nucl. Geophys. 6 293-300.

Virk H S, Walia V, Sharma A K, Kumar N and Kumar R 2000 Correlation of radon with microseismicity and meteorological parameters in Kangra and Chamba valleys of N-W Himalaya; Geofisica Int. 39 221-227.

Wakita H 1996 Geochemical challenge to earthquake prediction; Proc. Natl. Acad. Sci. USA 93 3781-3786.

Walia V, Lin S J, Hong W L, Fu C C, Yanf T F, Wen K L and Chen C H 2009 Continuous temporal soil-gas composition variations for earthquake precursory studies along Hsincheng and Hsinhua faults in Taiwan; Radiat. Meas. 44 934-939.

Walia V, Virk H S, Yang T F, Mahajan S, Walia M and Bajwa B S 2005 Earthquake prediction studies using radon as a precursor in $\mathrm{N}-\mathrm{W}$ Himalayas, India: A case study; TAO 16(4) 775-804.

Whitcomb J H 1983 Modeling of tectonophysical distortion from measurements of long base-line geodetic data and other geophysical parameters; NASA Grant No. NAG522 Semi-annual report, March-August 1980 (Colorado Univ.), 20p.

Yang T F, Walia V, Chyi C C, Fu C C, Chen C H, Liu T K, Song S R, Lee C Y and Lee M 2005 Variations of soil radon and thoron concentrations in a fault zone and prospective earthquakes in SW Taiwan; Radiat. Meas. 40 496-502.

Zmazek B, Todorovski L, Dmeroski S, Vaupoti J and Kobal I 2003 Application of decision trees to the analysis of soil radon data for earthquake prediction; Appl. Radiat. Isot. 58 697-706.

Zmazek B, Zivcic M, Vaupoti J, Bidovec M, Poljak M and Kobal I 2002 Soil radon monitoring in the Krsko Basin, Slovenia; Appl. Radiat. Isot. 56(4) 649-657. 